\title{
Environmental Restoration 1997 Annual Report
}

by

M. B. Cosper

Westinghouse Savannah River Company

Savannah River Site

Aiken, South Carolina 29808

This paper was prepared in connection with work done under the above contract number with the U.S.

Department of Energy. By acceptance of this paper, the publisher and/or recipient acknowledges the U.S. Government's right to retain a nonexclusive, royalty-free license in and to any copyright covering this paper, along with the right to reproduce and to authorize others to reproduce all or part of the copyrighted paper. 


\section{DISCLAIMER}

This report was prepared as an account of work sponsored by an agency of the United States Government. Neither the United States Government nor any agency thereof, nor any of their employees, makes any warranty, express or implied, or assumes any legal liability or responsibility for the accuracy, completeness, or usefulness of any information, apparatus, product, or process disclosed, or represents that its use would not infringe privately owned rights. Reference herein to any specific commercial product, process, or service by trade name, trademark, manufacturer, or otherwise does not necessarily constitute or imply its endorsement, recommendation, or favoring by the United States Government or any agency thereof. The views and opinions of authors expressed herein do not necessarily state or reflect those of the United States Government or any agency thereof.

This report has been reproduced directly from the best available copy.

Available to DOE and DOE contractors from the Office of Scientific and Technical Information, P. O. Box 62, Oak Ridge, TN 37831; prices available from (423) 576-8401.

Available to the public from the National Technical Information Service, U. S. Department of Commerce, 5285 Port Royal Road, Springfield, VA 22161. 


\section{DISCLAIMER}

Portions of this document may be illegible electronic image products. Images are produced from the best available original document. 


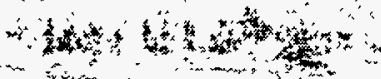

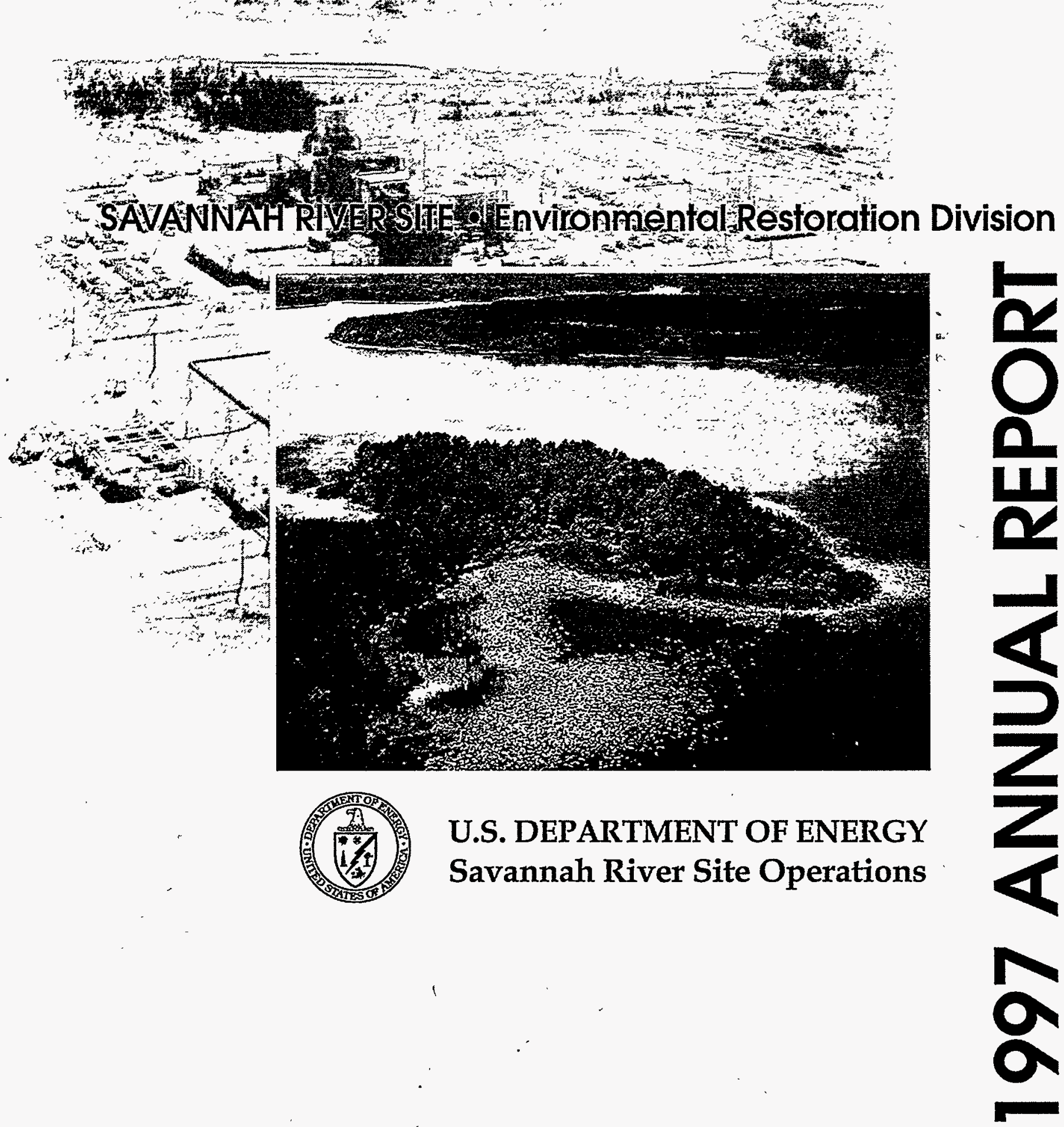




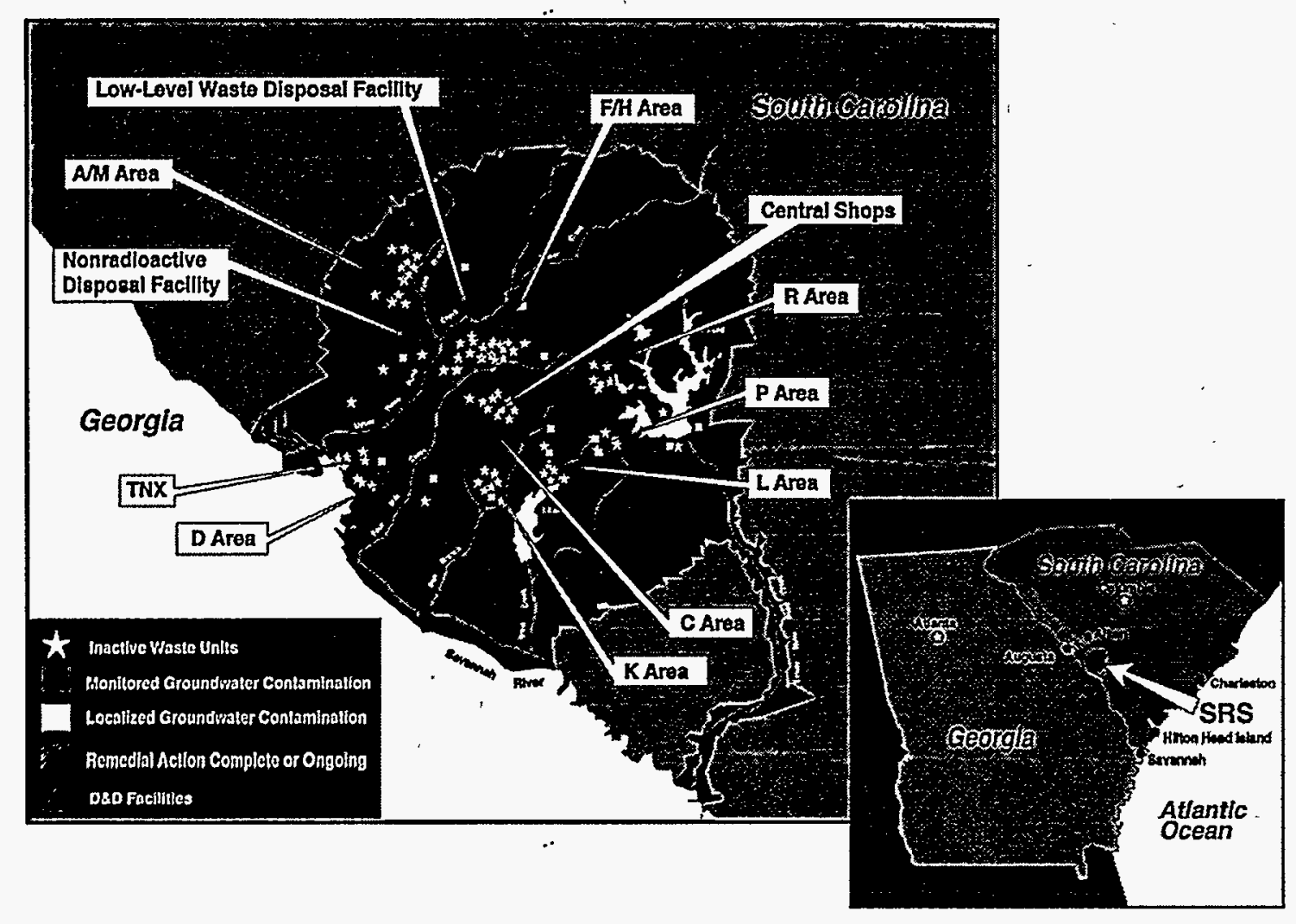

\section{SRS Environmental Restoration Program}

The Savannah River Site (SRS) is located on 300 square miles in central South Carolina bordering the Savannah River. The SRS Environmental Restoration Program was formed to clean up contamination that resulted from over 40 years of nuclear research and production to support our nation's defense.

Our Mission - Remedlate waste sites and groundwater units to reduce risk to the environment for future land use and to demonstrate capabilities to attract and succeed in new missions.

Our VIsion - Continuously exceed the needs and expectations of our customers and become recognized as best for environmental restoration through the application of innovative technologies, a strong commitment to teamwork, highly quallfied personnel, and attention to continuous improvement.

Princlples:

- Safety is our first priority

- People are our most important resource

- High Performance Teams are created and sustained

- Customer satisfaction is a confinuous focus

- Project management systems are rigorously used

- Long-range strateglc planning is valued

- Achieving excellence is a commitment 


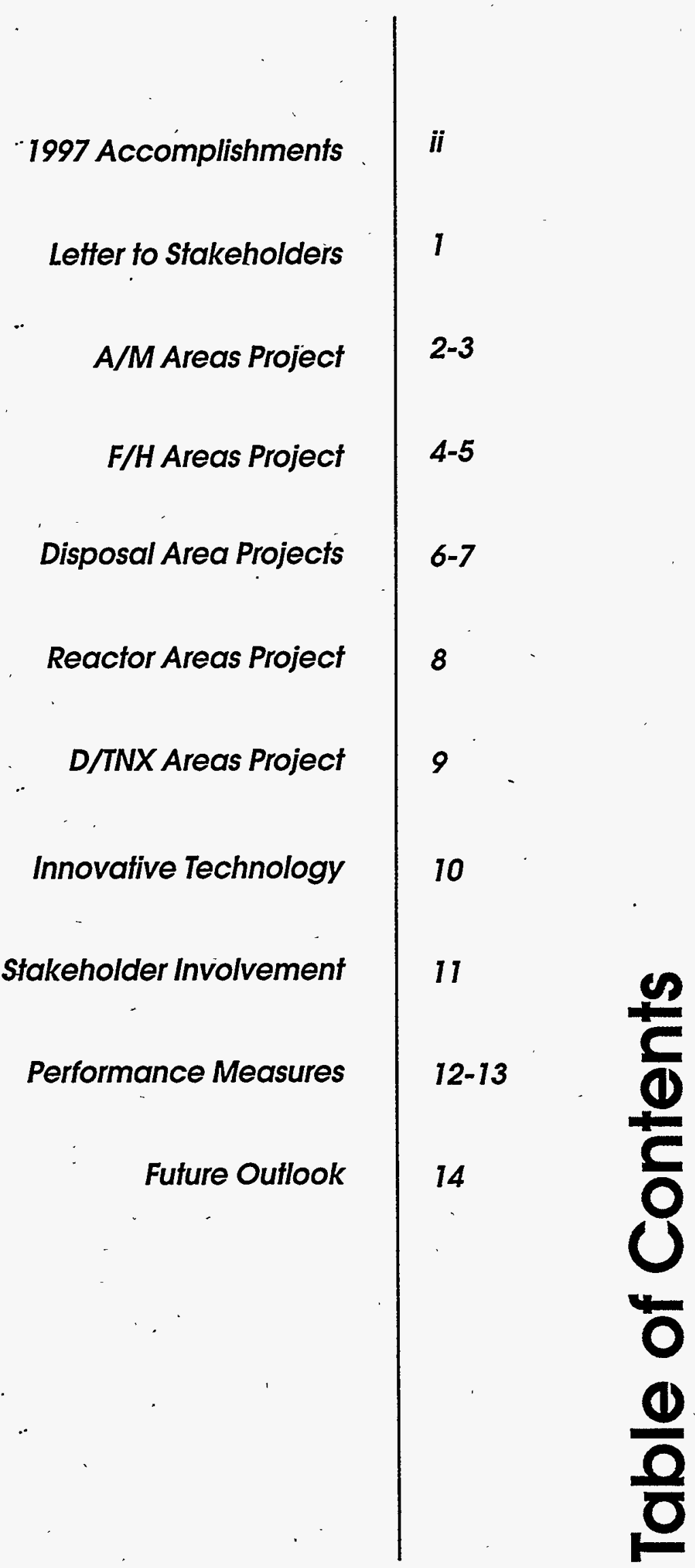




\section{Environmental Restoration Noteworthy FY 1997 Accomplishments}
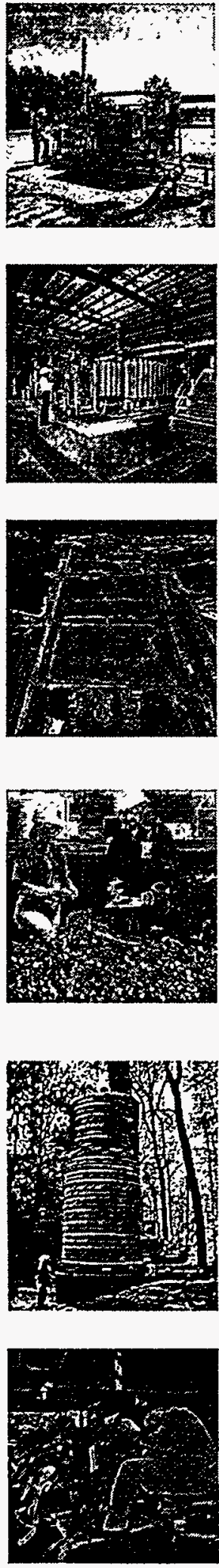

\section{Laboratory and Manufacturing (A\&M) Areas}

Almost 3 billion gallons of groundwater have been cleaned by removing more than 500,000 pounds of organic solvents. Soil Vapor Extraction Units that remove contaminants before they reach the groundwater have increased solvent removal rate by $500 \%$ versus conventional pump and treat methods. In situ treatment technologies such as airlift recirculation wells and subsurface injection of strong oxidizing agents have also been deployed.

\section{Separations (F\&H) Areas}

In $\mathrm{F}$ and $\mathrm{H}$ areas, thirty extraction wells and two reverse osmosis water treatment facillties were installed and brought on line 6 months ahead of the regulatory commitment. The water treatment units are designed to remove radlonuclides and heavy metals. The treated water will be reinjected Into the ground upgradlent from the seepline to establlsh hydraullc control of the tritium contamination plume.

\section{Disposal Areas}

Construction of a low permeabllity interim soll cover over the 76-acre Old Radloactive Waste Burial Ground was completed 4 months ahead of the regulatory commitment date. This interim action prevents rainwater infiltration while the final remedial action for this waste site is being considered. Construction of a RCRA-permitted geosynthetic cap was completed at the 55acre Nonradioactive Disposal Facility.

\section{Reactor Areas}

An innovative plan for recycle and reuse of the waste materials contained in four inactive coal pile runoff basins resulted in an 11 million dollar cost savings and a 92-month schedule acceleration. Removal of radioactive contaminated vegetation was completed at the $C, K$, and $R$ Area Reactor Seepage Basins.

\section{Power and Pilot Plant (D/TNX) Areas}

The GeoSiphon Cell, developed by the Savannah River Technology Center, is an emerging technology being evaluated to treat chlorinated volatile organic contamination at the TNX Area. This method takes advantage of natural groundwater flow to funnel contamination into a treatment bed filled with granular iron and other materials that decompose the contaminants to environmentally safe compounds.

\section{Innovative Technologies}

Portable gamma detectors greatly reduced characterization and contaminated vegetation removal costs by supplying real time gamma contamination data for waste site characterization and waste segregation. 


\section{Letter to Stakeholders:}

Breakthrough is a term used when obstacles must be overcome to attain performance improvement to levels not possible before.

During 1997, the Environmental Restoration Program at the Savannah River Site achieved all of the "Breakthrough Goals" that were established with our regulatory agencies in 1995 to advance our cleanup efforts. Effective focus on field remediation was demonstrated by the allocation of $75 \%$ of program funding to remediation activities. The Remediation Phase is complete or has begun on sixty-nine waste sites that represent approximately $80 \%$ of the known environmental and health risk. The average time required for the assessment phase of active projects was reduced by $50 \%$, from 49 to less than $\mathbf{2 4}$ months, which allows cleanup actions to start twice as fast as before.

Breakthrough performance has tangible results. During 1997, all of the funding allocation was used effectively to accomplish environmental restoration scope worth over $\$ 123$ million. That represents a validated cost efficiency of over $20 \%$ for the third straight year. Over half of the 500 contaminated acres at SRS have been cleaned up or are currently in the remediation phase. Almost 3 billion gallons of groundwater have been restored by removing over half a million pounds of organic solvents.

Aggressive application of innovative technologies and methods helped drive down costs. A recycle and reuse strategy for cleaning up inactive coal pile runoff basins alone yielded efficiencies of over $\$ 11$ million. New groundwater treatment methods such as underground airlift recirculation and insitu chemical oxidation are reducing cleanup costs by over $50 \%$ as compared to conventional above ground pump and treat methods. Innovative characterization technology deployments such as portable gamma radiation monitors, real-time remote contamination sensing equipment, and mobile on-site laboratories are also improving costs and schedules.

The DOE contract with Westinghouse to manage operations and environmental management at SRS now includes the Bechtel Savannah River Inc. with overall responsibility for environmental restoration. Exceeding cleanup goals safely and cost effectively will be the top priority of this team. Disciplined project management, process and technology innovations, as well as excellent customer and stakeholder relations will be the key focus areas to ensure continued excellence.

During 1997, over half of the budget was utilized through subcontracts that tapped the expertise and resources of the best environmental restoration contractors in the industry. We also established new contracting methods to enhance safety performance at all ER work sites. These efforts helped to realize our highest goal of zero lost time due to injuries on all projects.

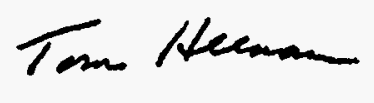

Tom Heenan Assistant Manager Environmental Quality DOE-Savannah River

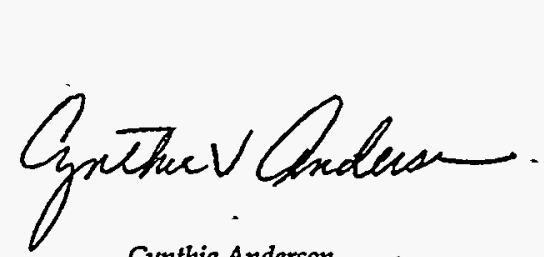

Cynthia Anderson

Director

ER Division

DOE-Savannah River

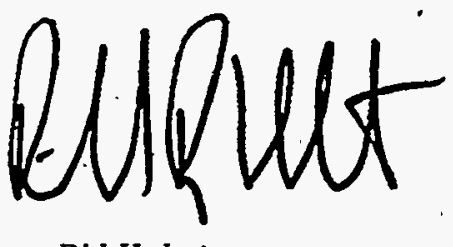

Dick Harbert Vice President and General Manager ER Division WSRC-Savannah River 


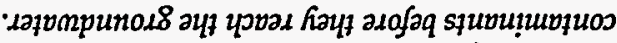
fuaros anowas st?
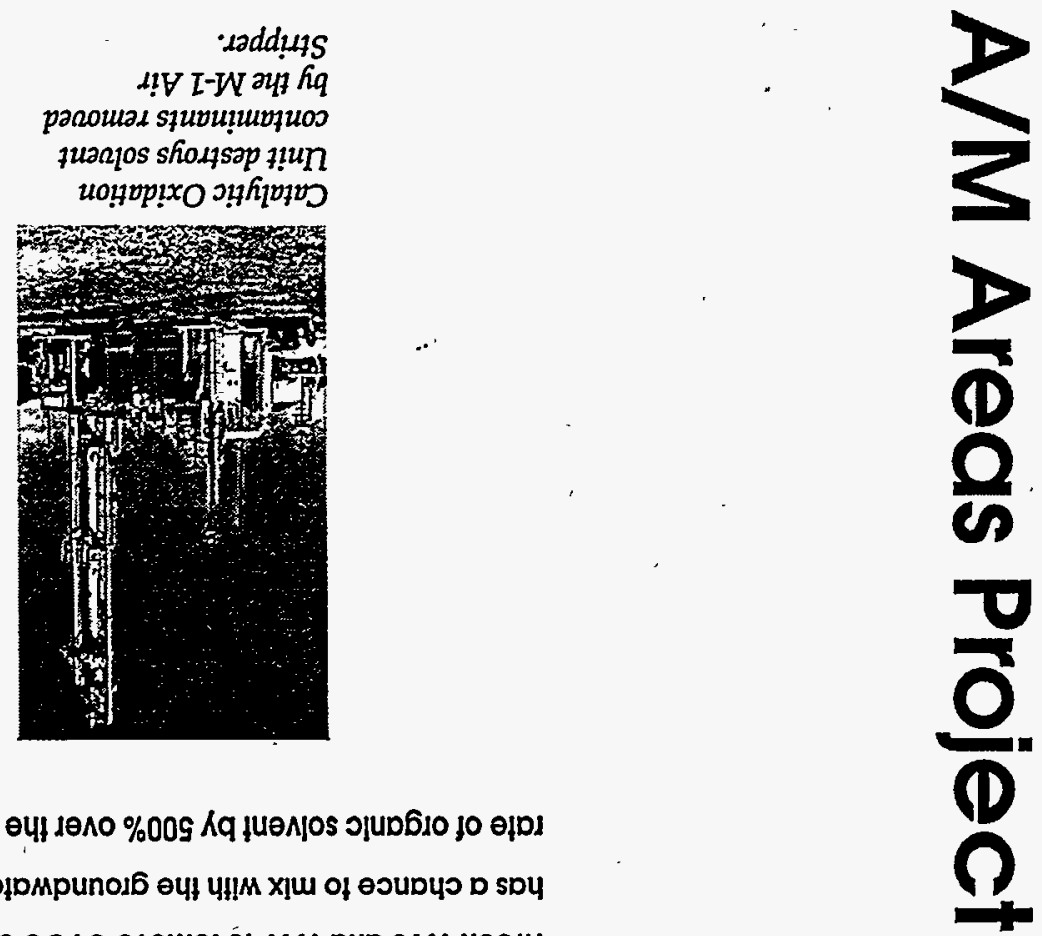

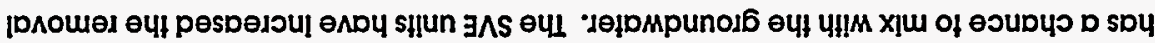

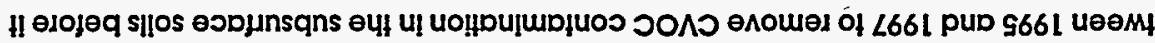

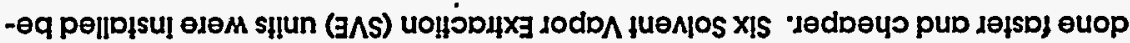

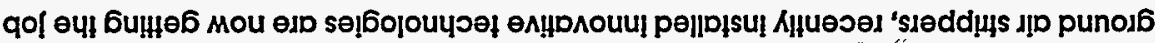

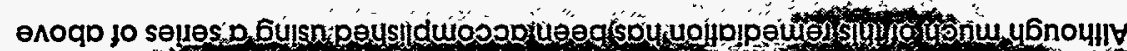

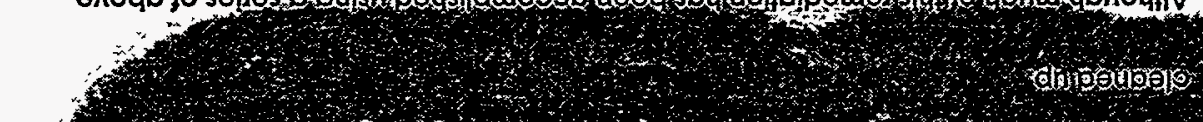

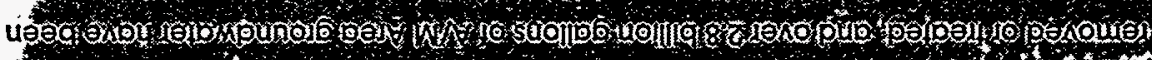

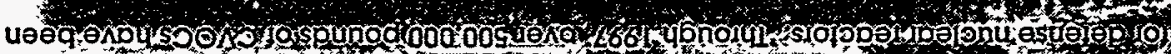

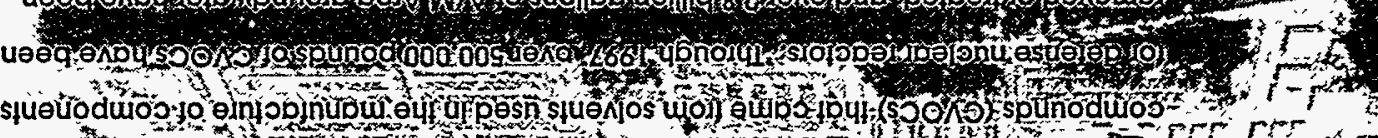

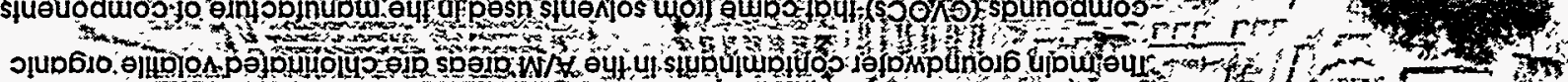
$x=0$

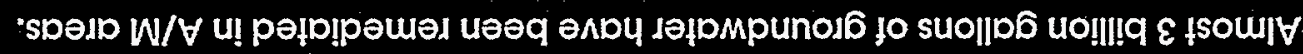

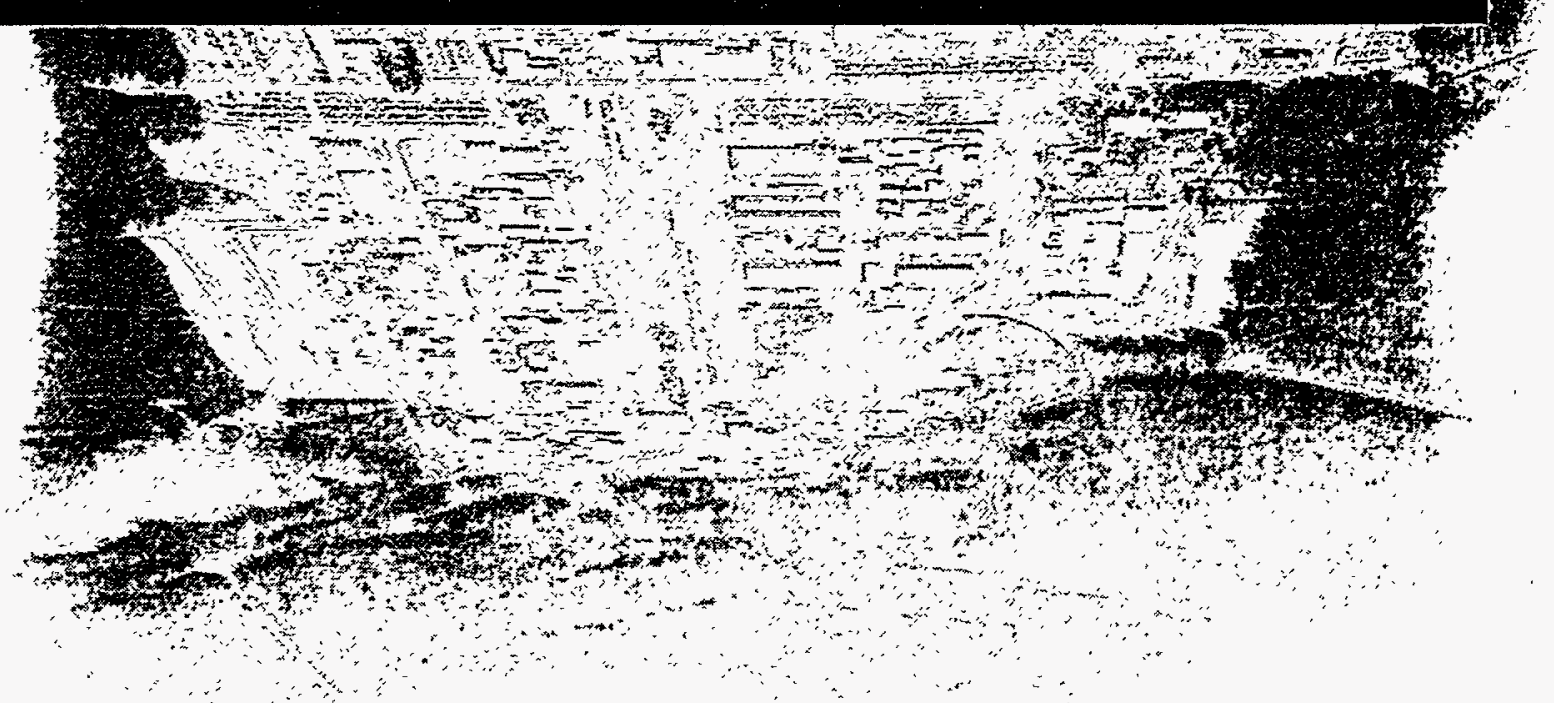




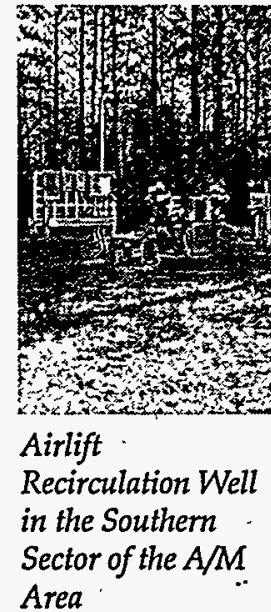

During 1997, efforts have shiffed foward in situ cleanup, which means to remove or destroy the contamination without pumping the groundwater to the surface.

One in situ treatment technology that was demonstrated in the A/M area involved chemical oxidation, also known as Fenton's Chemistry. A patented Injection system was Insialled to diffuse and alsperse a powerful solution of oxldizers and catalysts to the groundwater. The process increases the permeability of most subsurface solls and then chemically destroys the organic contamination within the treatment area.

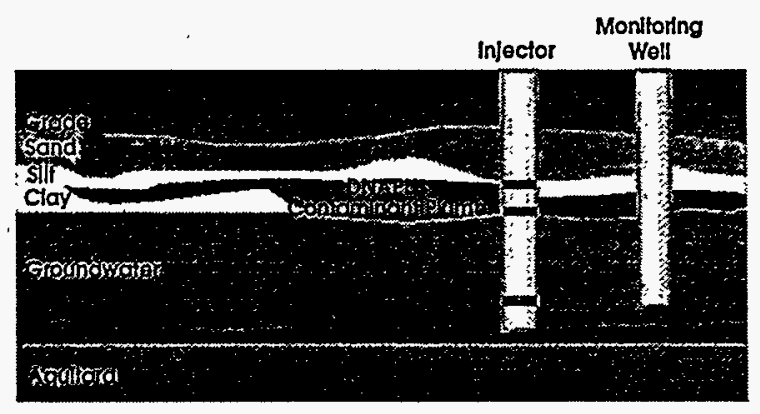

Fenton's Chemistry Technology destroys solvent contaminants by oxidation.
Two airlift reclrculation wells have been Installed at the leading edge of the southem sector groundwater contamination plume. This technology consists of two concentrlc well pipes with upper ................... and lower batfles and screens. Alr is pumped down the center well which then fravels upward in the outer well, in effect, creating an in situ air stripper. The upward air flow strips out the CVOC contamination and establishes a recirculating flow which brings in more groundwater to be cleaned. The airlift recirculation method cuts treatment costs in half compared to above ground air stripplng.
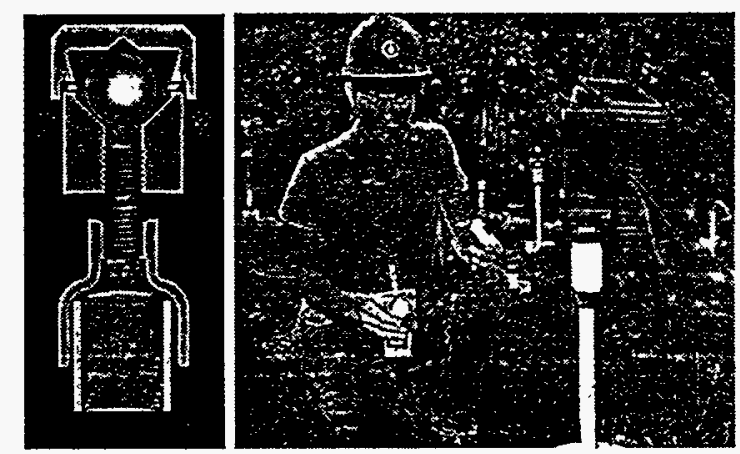

The BaroBallTM, developed by Savannah River.

At several locations in A/M area, a less aggressive, costelfective technology was deployed to remove low concentraHions of CVOCs from the soll. The BaroBalrm, developed at SRS, maximizes the use of natural atmospheric pressure changes to remove solvenis without mechanical pumping. When à low pressure weather system occurs, solvents can be naturally removed from the ground through perforated vertical wells Installed in the contaminated soll. The BaroBallim prevents the Inflow of air back into a venting well when high atmospheric pressures dominate. If air enters the venting well, contaminanis would be pushed away from the well and take longer to remove. By insialling a simple plastic sphere in a well, solvents can be removed whille air is kept from entering the well as weather patterns change. The BaroBalpm actually speeds up what Molher Nature has provided as a simple cleanup method. 


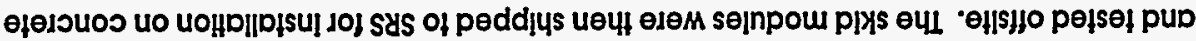

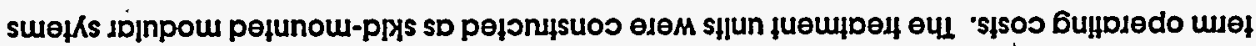

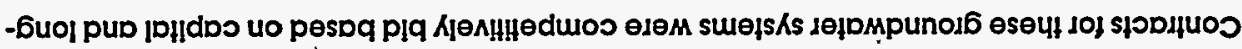

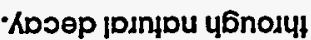

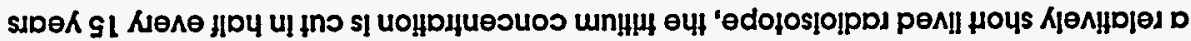

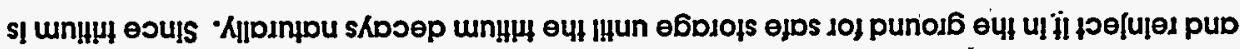

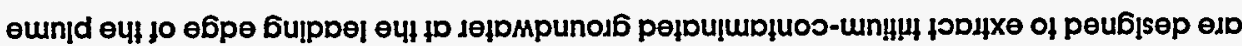

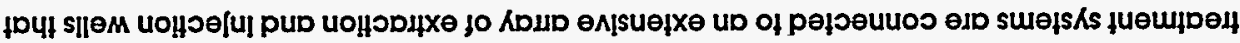

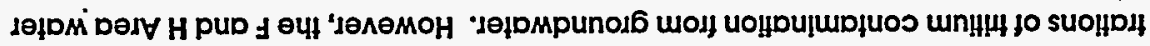

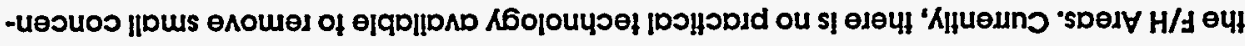

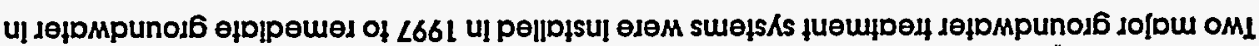

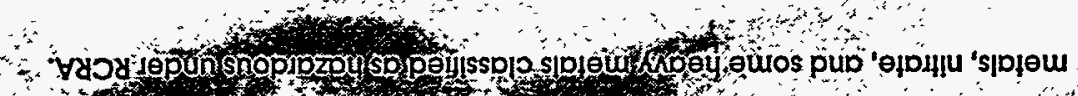

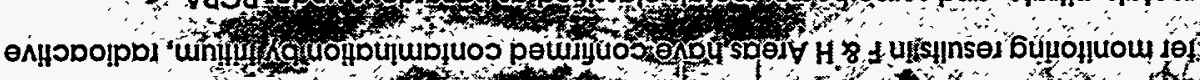

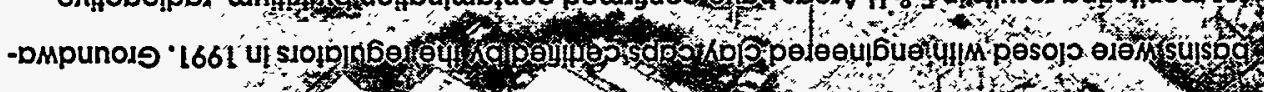

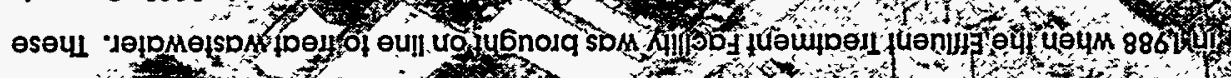

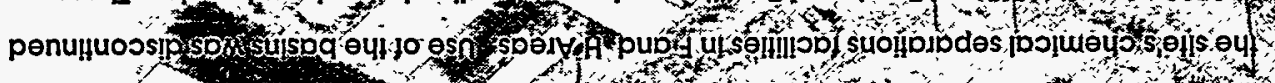

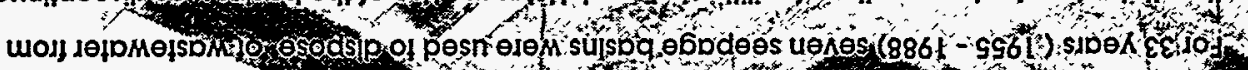

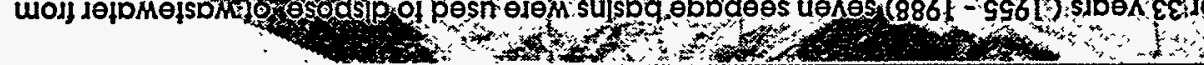

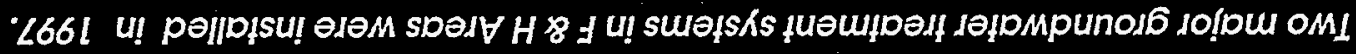

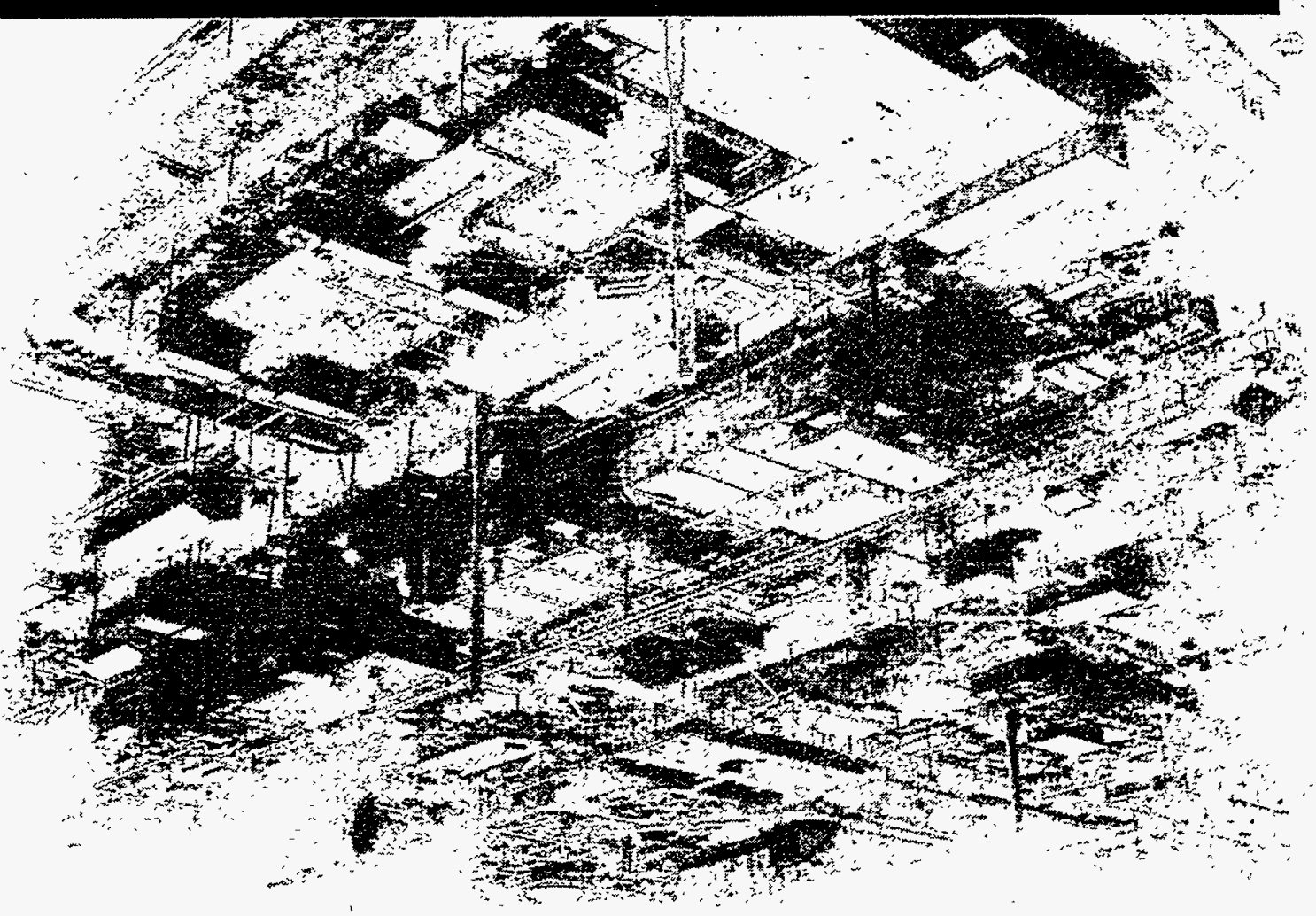




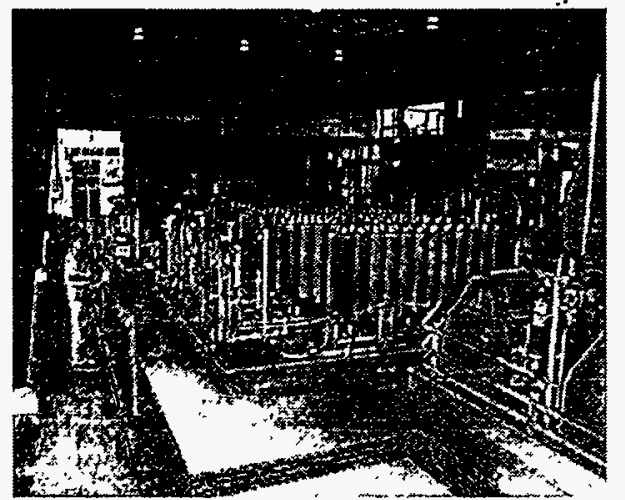

F-Area Groundwater Treatment System engineer, Brad Davis, takes readings for process control.

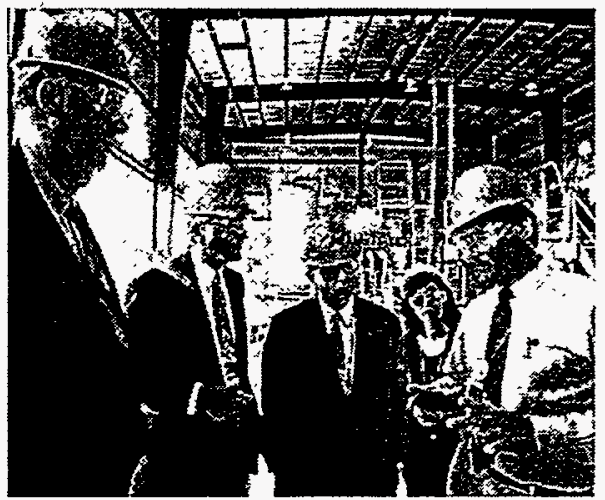

Bechtel Savannah River, Inc., Board of. Directors are briefed on $\mathrm{F} / \mathrm{H}$ Area groundwater treatment progress.

foundations and connected to the extraction/injection well network. These innovative consfruction methods saved three million dollars in construction costs and shaved five months off the original regulatory commitment schedule.

Additional testing has demonstrated that further improvements in operation of the new groundwater treatment units are possible. Nanofiltration, a new fype of membrane filter treatment fechnology, was tested for its ability to reduce expected waste stream volumes. These tests have shown that as much as $\mathbf{8 0}$ \% reduction in waste volume is possible which could translate to annual savings of several hundred thousand dollars.

Four remaining inactive seepage basins in the $F \& H$ Areas are beling assessed for remediation. These basins were used for confainment in emergency sifuations and for temporary storage of potentlally contaminated storm water runoff and process cooling water. Contaminated vegetation at these sites has been cut down and readled for final disposal. A Record of Decision (ROD) has been reached with the regulators for final closure of the Old F-Area Seepage Basin. The ROD calls for stabilizing confaminants by mixing the soll with grout (a cementacious material) and capping with a low permeability clay/soll cover. This remedial action will begin in 1998.

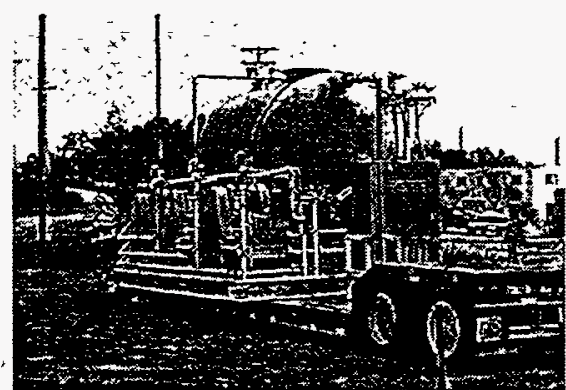

Delivery of modular groundwater treatment units to SRS.

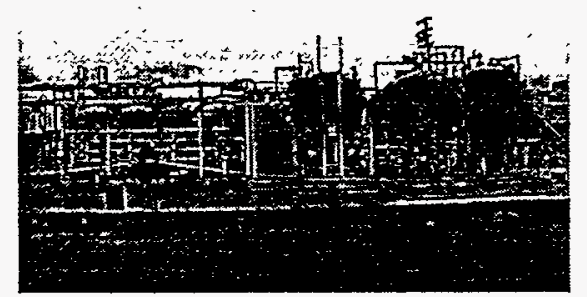

Installation of modular units is much faster than complete onsite construction. 

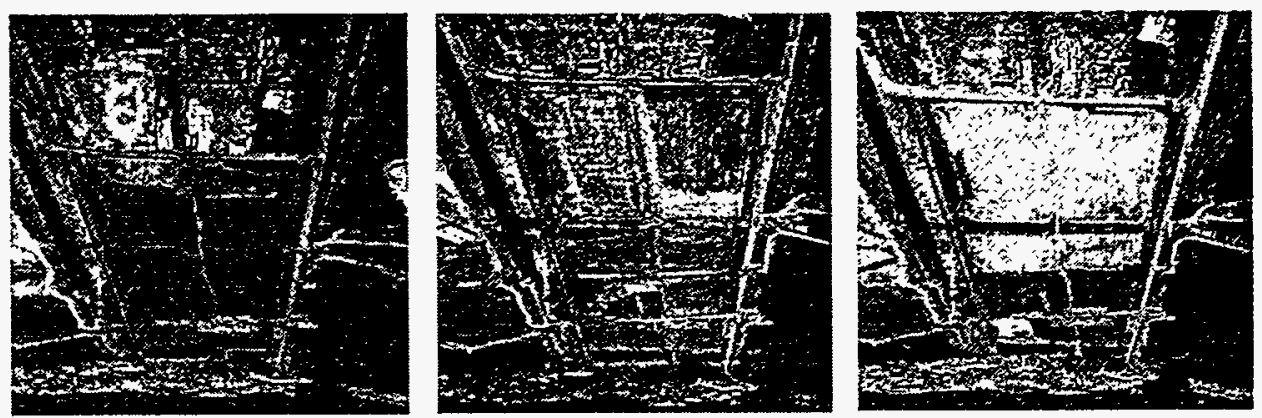

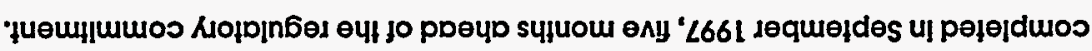

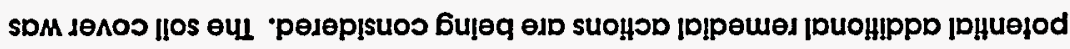

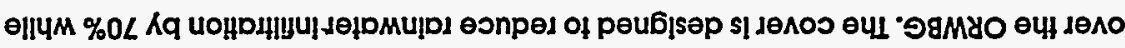

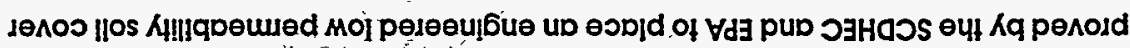

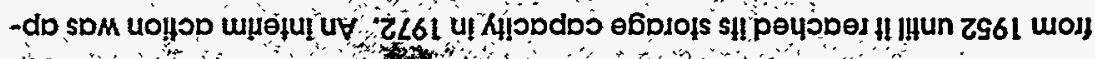

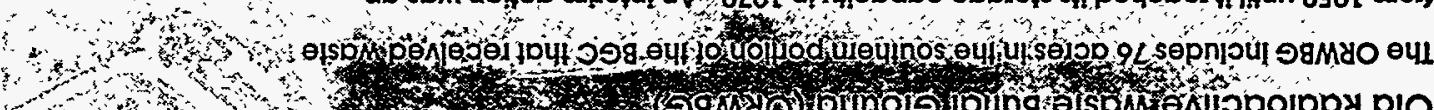

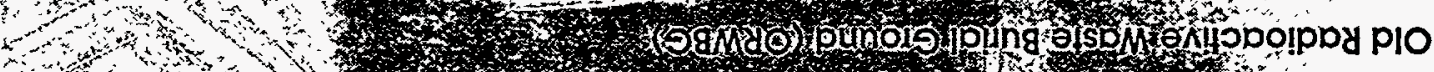

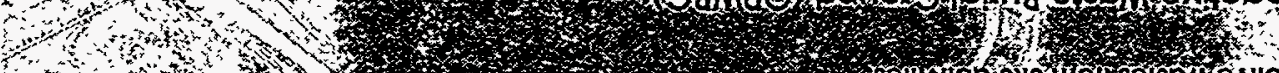

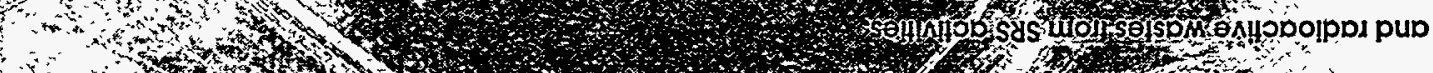

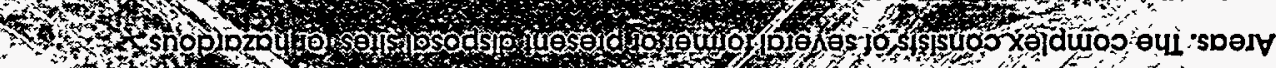

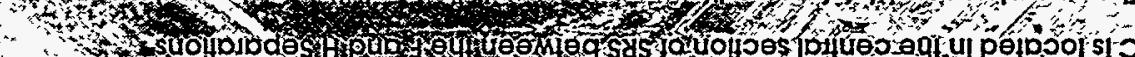

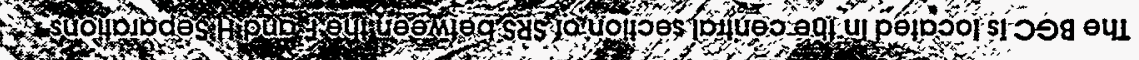

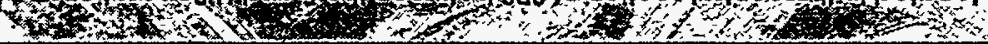

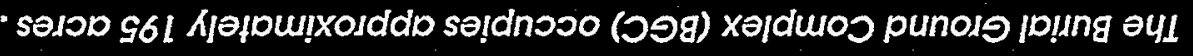

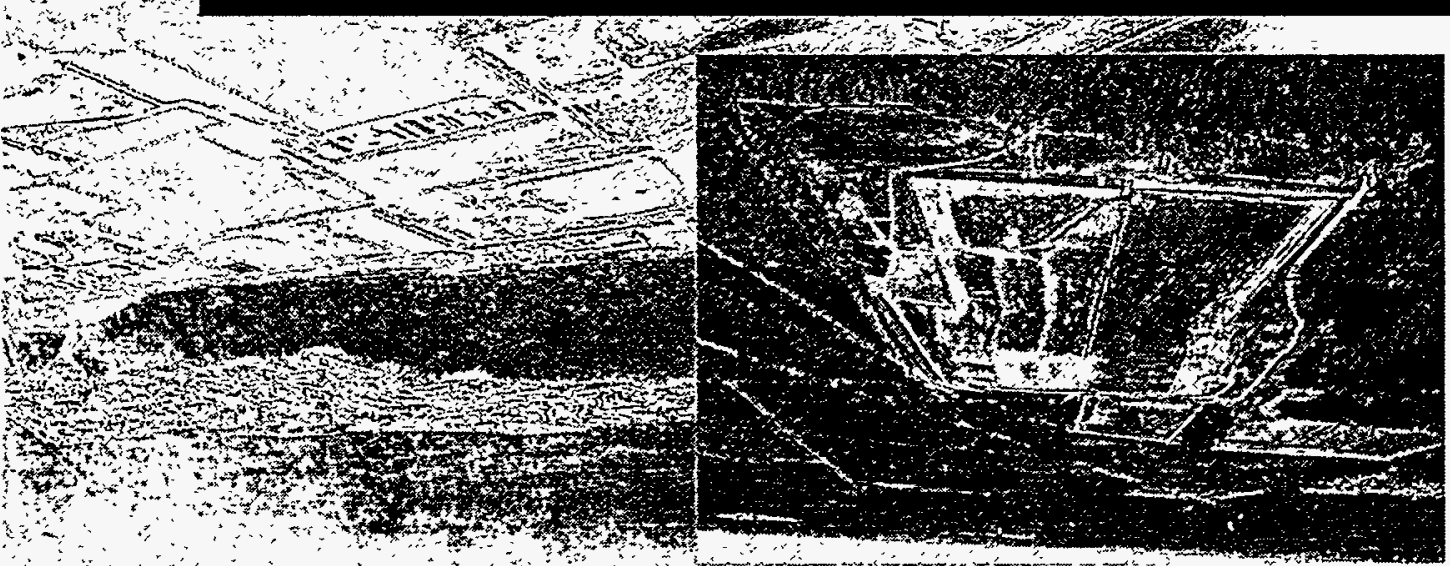


Low-Level Radioactive Waste Disposal Facility (LLRWDF):

The LLRWDF occupies 119 acres in the northern portion of the BGC, Thls facllity began recelving wastes in 1970, and some sections are still in use today. Two sections of the LLRWDF, comprising 5 acres, were stabilized and then

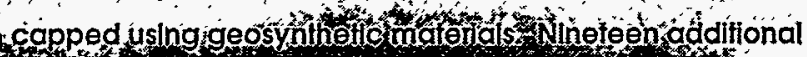

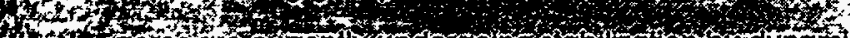

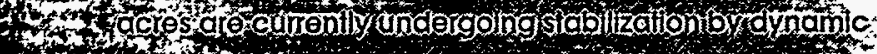

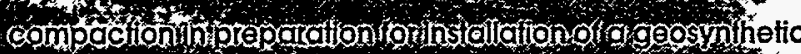

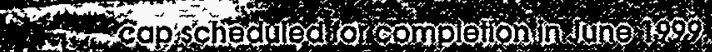

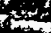

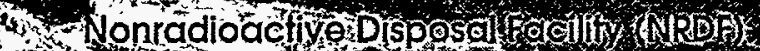

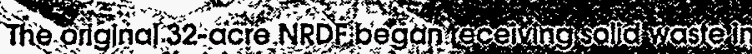

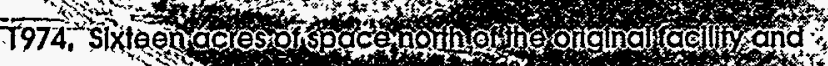

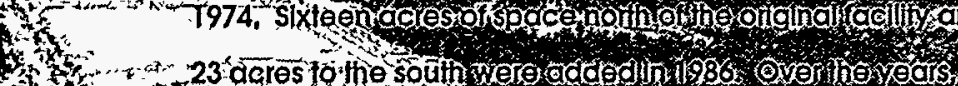

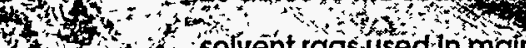

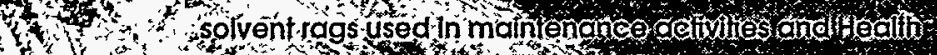

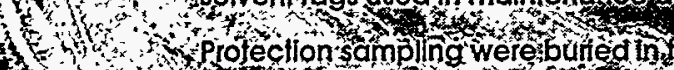

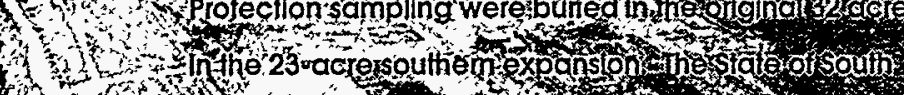

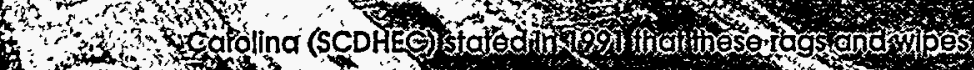

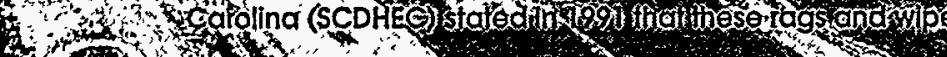

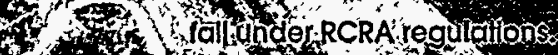

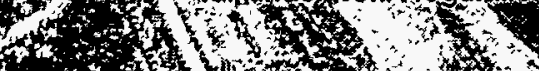

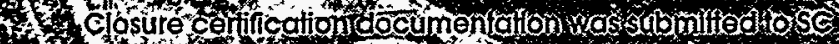

b HEC in Jaly 1997 for 55 acres of the Non

Facillfy (NRDF): The NRDF

closure utilized the first

geosynthetic capping

system approved for a

hazardous waste closure

In South Carolina.

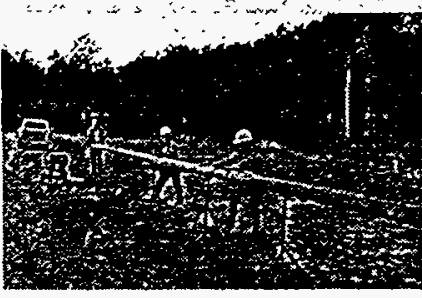

Technicians weld $6^{\prime \prime}$ diameter casings together for a $1400 \mathrm{ft}$. horizontal well at the NRDF.

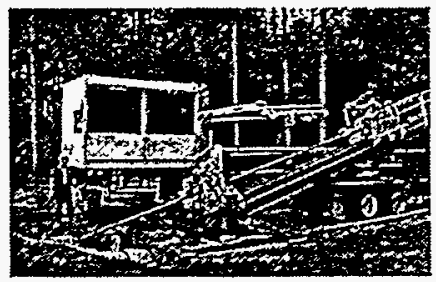

Horizontal Well Drilling Rig
Dynamic Compaction to prepare LLRWDF for geosynthetic cap
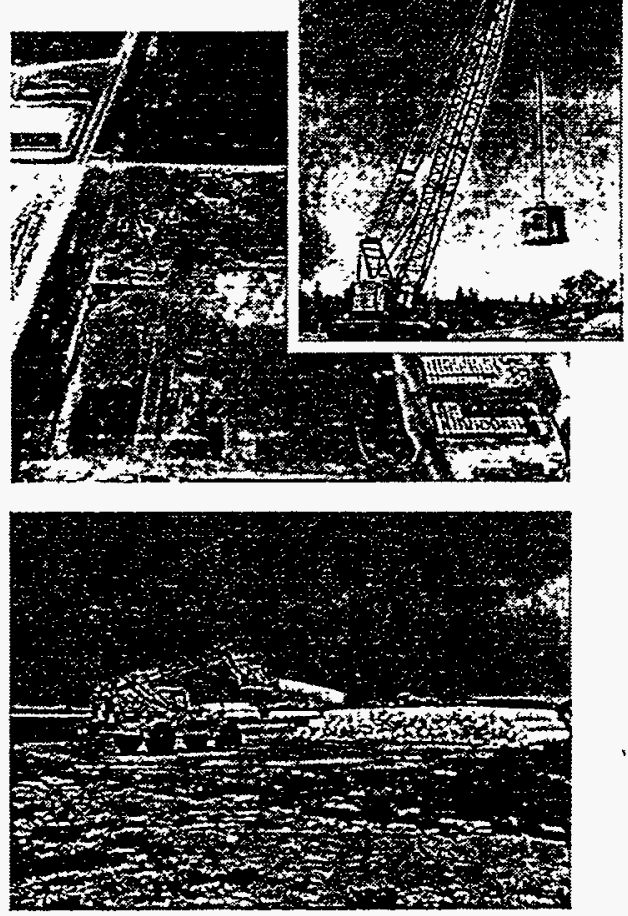

Geosynthetic materials ready for LLRWDF cap construction
In situ bioremediation project commences at the Nonradioactive Disposal Facility (NRDF):

Drilling has begun for the placement of two horizontal wells at the NRDF that will be used for in situ bloremediation of solvent contaminated groundwater. At $1400 \mathrm{ft}$. in length, the wells are among the longest in the nation used for remediation. The innovative design of the wells will allow changing the well screen design parameters with minimum effort. The design utilizes a 6 inch carbon steel outer casing pipe and a 4-inch high density polyethylene inner casing. The Inner casing can. be removed, the screen zone reconfigured, and the inner casing replaced with minimum effort. 


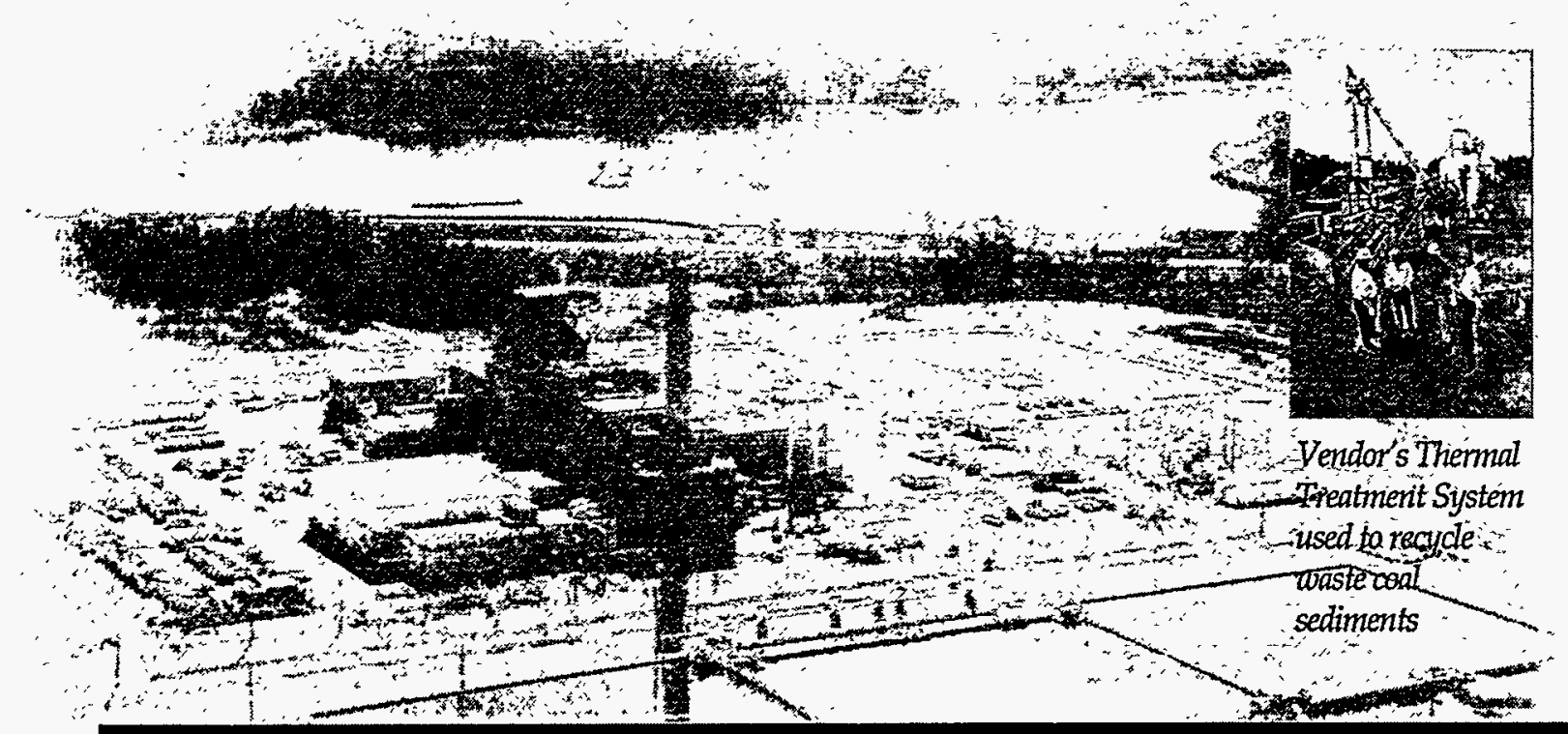

Remediation of 4 Coal Pile Runoff Basins accelerated by 92 months and saved $\$ 11$ million.

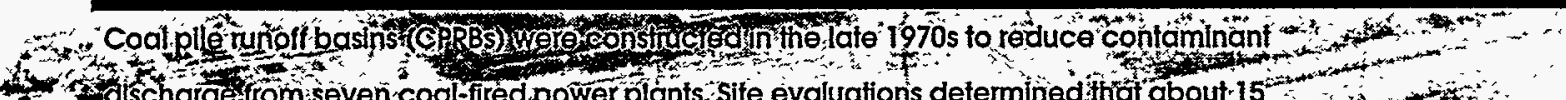

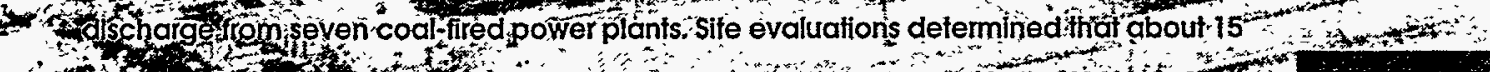

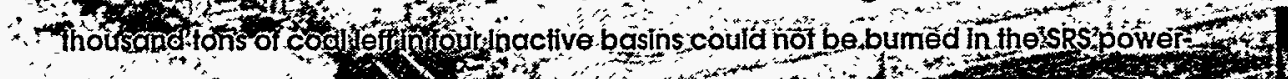

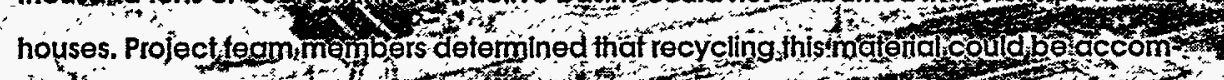

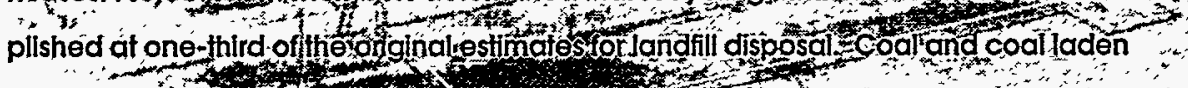

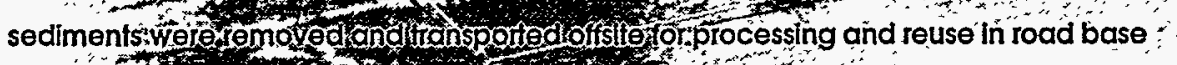

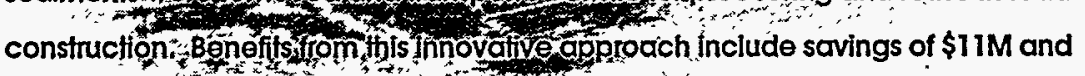
schedule acceleration of 92 months over original estimates. This is the first time SRS has released and recycled waste for public use from a CERCLA waste site.

\section{Real-Time Contamination Data from Portable Gamma Probes}

The Enhanced Spectral Gamma Probe, developed by the Corps of Engineers, was deployed at the R-Reactor Seepage Basin for subsurface characterization. The Gamma Probe was mounted on the tip of a direct push cone penetrometer fo measure gamma contamination at varying depths. This technology eliminates the task of taking soll samples as well as fransporting, controlling and analyzing the samples at an offsite laboratory.

A portable sodium lodide gamma probe was mounted In a hand-held boring fool for real-time measurement of gamma radiation emilted by contaminated vegefaflon. The Instrument was deployed at the C-Reactor Seepage Basins to segregate trees into clean and contaminated categories.to save on disposal costs.

\section{Early Actions Remove Contaminated Vegetation}

Radioactive contaminated vegetation was removed from the Old F-Area Seepage Basin, Reactor Seepage Basins in C, P, L and K Areas, SRL Seepage Basins and the K

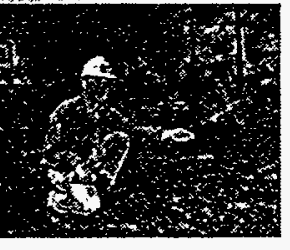

15,000 tons of unusable coal earmarked for recycle

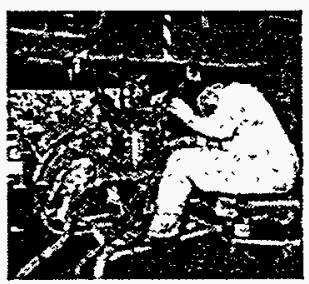

Cone Penetrometer Mounted Gamma Probe

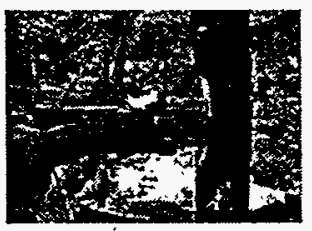

Hand held Gamma Detector Area BIngham Pump Outage Waste Site. The contaminated vegetation Is being prepared for final disposal. 


\section{TNX History:}

The TNX Area is a pilot scale festing facilify that supports SRS operations. Product and process testing over the past $\mathbf{4 0}$ years has released relatively small amounts of organic solvents and Inorganic salts to the groundwater.

Regulators approved an inferim action to Install proven air stripper technology to gef an early start on removing chlorinated volatile organic compounds (solvents) from INX Area groundwater. After the first 12 months of operations, the T-1 Air Stripper has remediated over $\mathbf{2 0}$ million gallons of solvent-contaminated groundwater. Our commitment, established between Secretary O'Leary and President Cllnton, is fo remediate 35 million gallons of TNX Area groundwater by October 1, 1998.

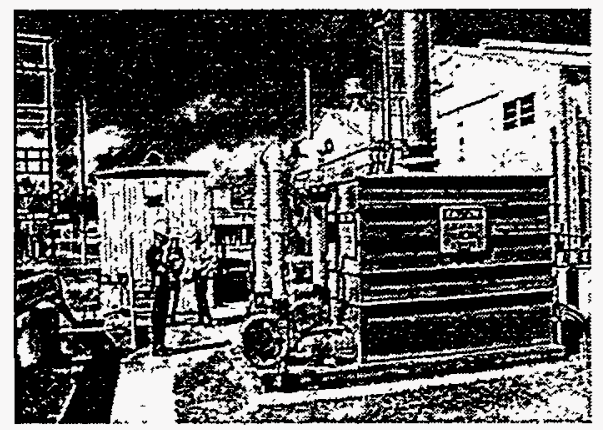

Low-profile Air Stripper remediates groundwater at TNX Area

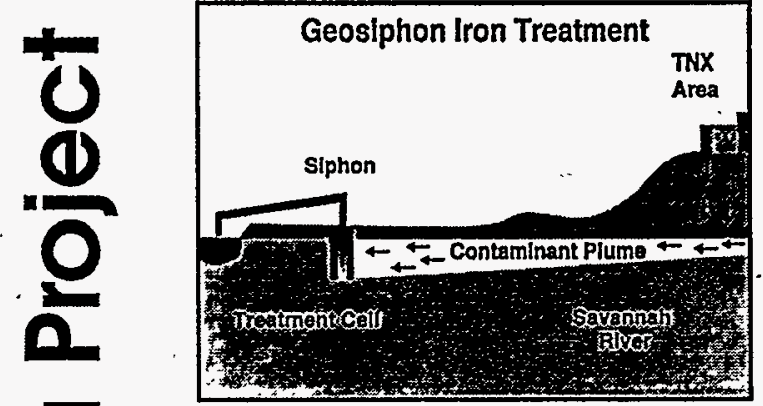

The GeoSiphon System takes advantage of natural groundwater flow and hydraulic head to draw in groundwater for treatment and discharge the remediated water to the Savannah River.

\section{GeoSiphon Technology Deployment:}

The GeoSiphon Cell is an emerging technology developed by the Sorvannah River Technology Center. It is being evaluated for in situ treatment of CVOCs at the TNX Area and is sultable for treatment of sites with relatively shallow contamination. This treatment system may also be used to treat certain types of radiological contamination.

The GeoSiphon Cell is essentially a large diameter well that can be packed with treatment media such as granular cast iron, activated carbon, cation exchange resin and limestone or zeolite. The treatment media used at TNX is granular cast iron. Natural hydraulic pressure draws contaminated groundwater through the cell where solvent contaminants are remediated fo meet Primary Drinking Water Standards. Degradation products are ethane, methane and chloride ions. Flow of groundwater through the treatment cell is induced by the natural hydraulic head difference between the cell and the Savannah River. The treated water is subsequently discharged into the Savannah River.

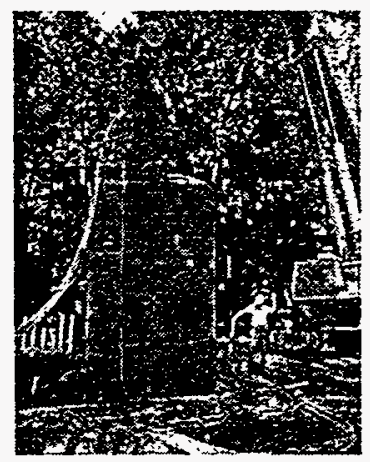

A 45 ton pneumatic hammer was used to advance a 25 ft. long by 8 ft. diameter caisson to install the GeoSiphon cell.
The GeoSiphon Cell should prove to be less Intrusive, less expensive, more efficient, and - less susceptible to pluggage than other fechnologies considered for this application. Phase I festing dala from the Geosiphon Cell shows that solvent contamination on the order of $\mathbf{2 0 0}$ parts per billion in the groundwater is reduced to less than defectable levels after treatment. 


\section{Innovative Technologies Are Being Applied to Groundwater Cleanup at SRS}
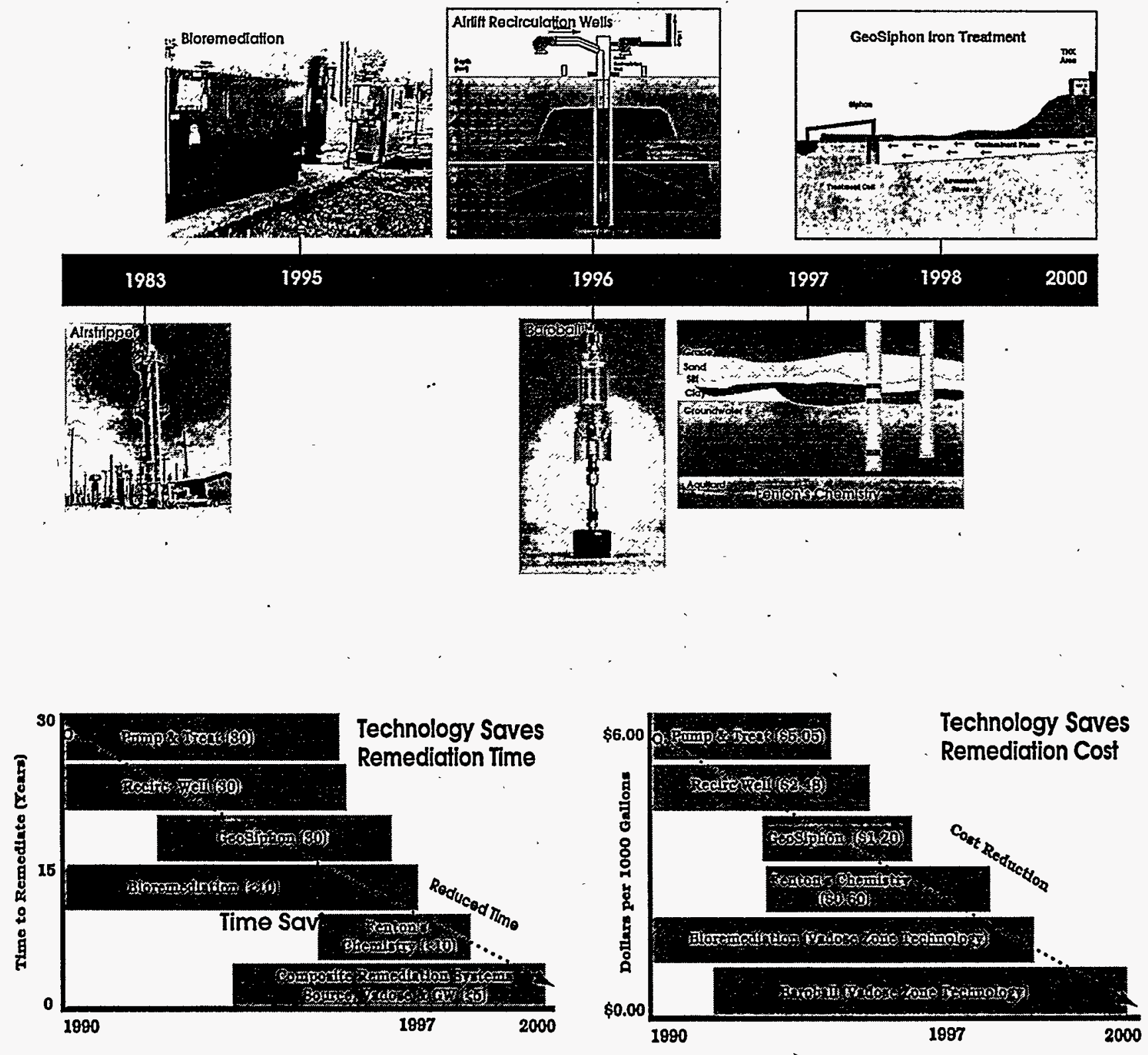

Early efforts to clean up groundwater at SRS utilized aboveground airstrippers with a cost of about $\$ 5.05$ per 1000 gallons frealed and tofal remediation time estimated at 30 years. Recent efforts to develop new and innovative technologies have ylelded more cost effective treatment alternatives that also greatly reduce the time required to remedlate SRS groundwater. 
Stakeholder Involvement at SRS includes the public, the South Carolina Department of Health and Environmental Control and Region 4 of the Environmental Profection Agency.

SRS strengthened public participation in 1994 with the formation of the Citizens Advisory Board (CAB), comprised of 25 nonpartisan, independent citizens. Recognizing the large number of

- projects on the cleanup schedule for SRS, in 1997 the CAB presented a recommendation for all three agencies; EPA. SCDHEC, and DOE at SRS to work more closely together to expedite actual field clean-up work and develop an early action framework for the high risk waste sites at SRS.

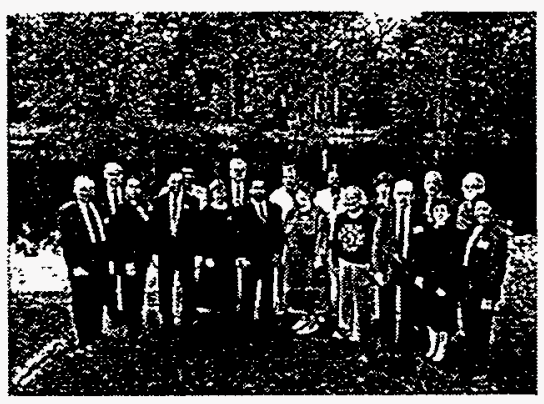

1997 Citizens Advisory Board (CAB)

The CAB also recommended developing screening criteria to identify the lowest risk RCRA/CERCLA sifes. This action significantly shortened the process for reaching limiled or no action remedial decisions for lowrisk sites. The final part of this official recommendation called for continuing acceleration of the ER program to determine which site evaluation areas required no further action.

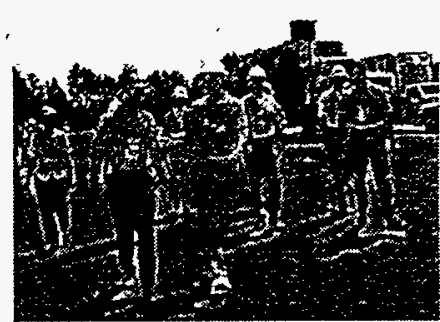

Dick Green, Director EPA Region 4, inspects Gamma Probe mounted on a Cone Penetrometer at the R Reactor Seepage Basins. This innovative technology deployment provides real time radiological data for subsurface contamination.

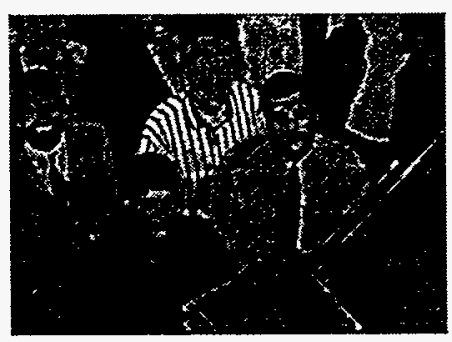

SCDHEC Project Managers Keith Collingsworth and Jeff Crane confer with $C A B$ members to achieve common goals.
EPA and SCDHEC participation in "Breakthrough" meetings and workshops that began in the summer of 1995 resulted in commitments that drove performance for the next three years. Performance gains in the areas of risk reduction, focus on remediation and streamlined document processes were achleved.

The Breakthiough Process continued in 1997 with the agreement by both EPA and SCDHEC to delegate decision making for technical issues to the technical experts. This agreement will improve the entire document development and review process by fostering greater ownership by the experts.

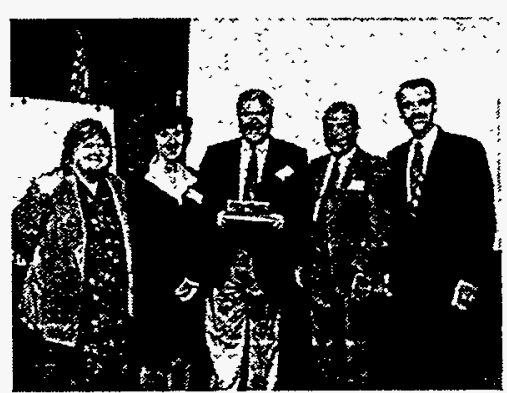

Regulators and SRS DOE encourage public involvement to help define initiatives amd enhance ' communications. 


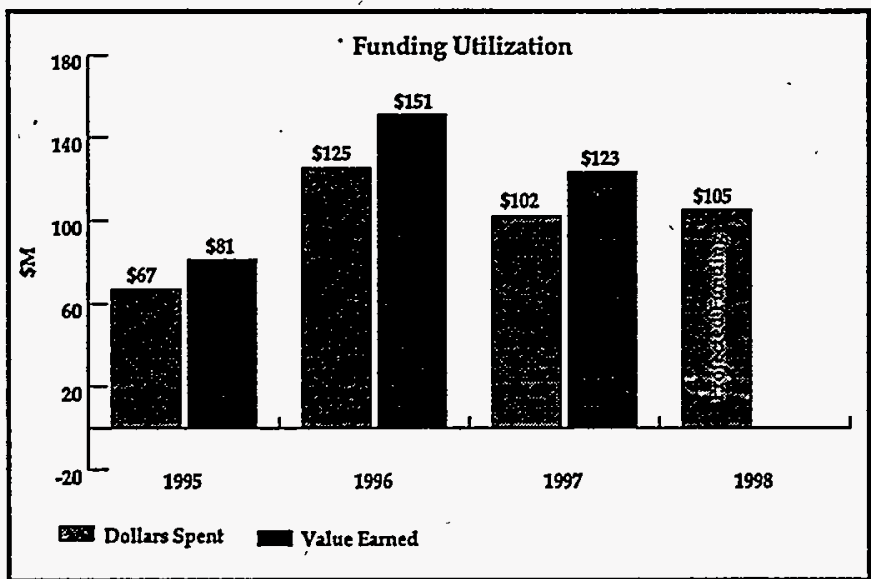

Cost efficiencies of over $20 \%$ have been achieved for each of the last 3 years. Cost savings were reinvested in the program to accomplish additional prioritized and approved scope.

The focus is clearly on cleanup work. In two years, the percentage of funding going to remediation activities versus assessment increased from $40 \%$ in 1995 to $75 \%$ in 1997.
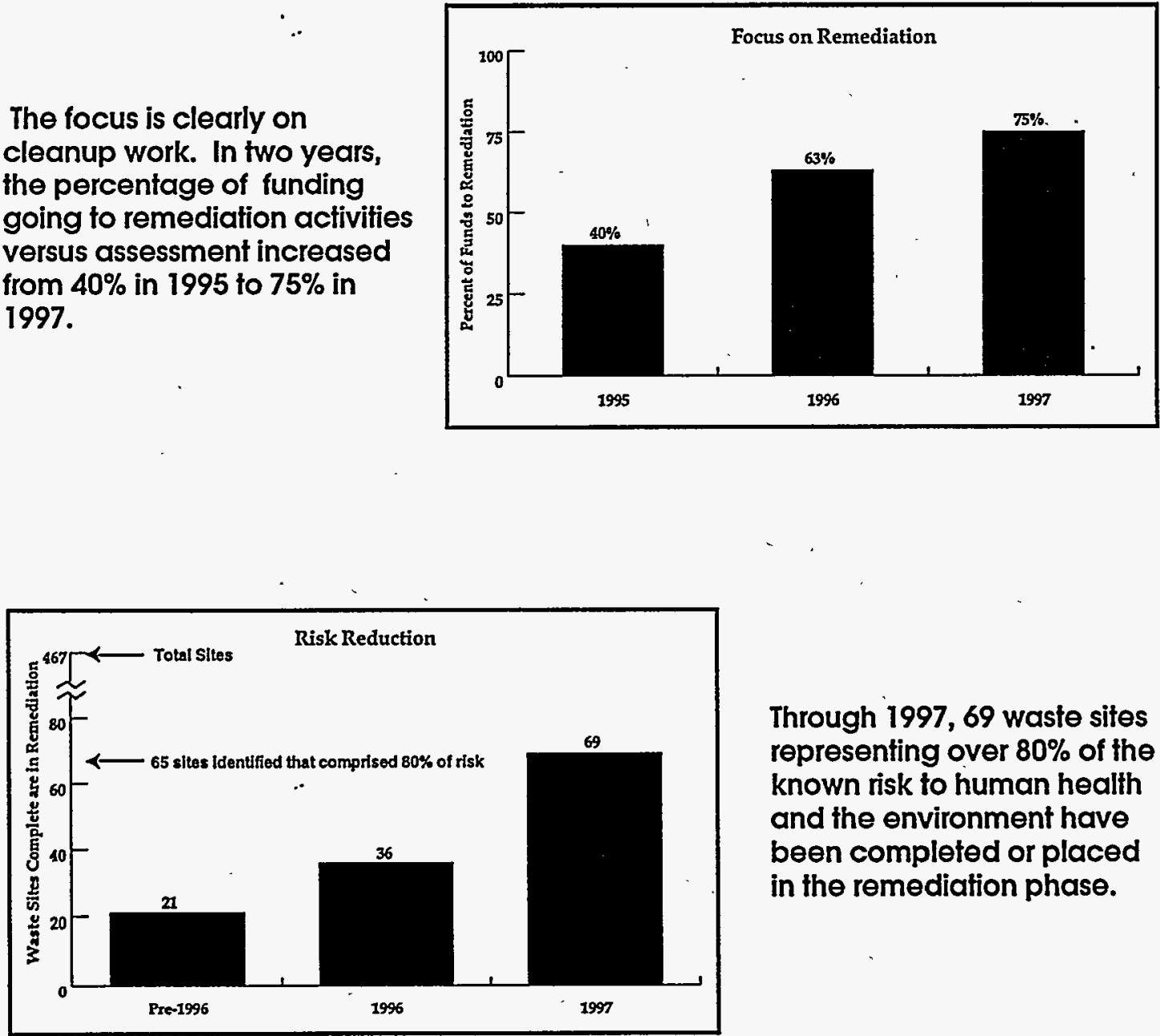

Through 1997, 69 waste sites representing over $80 \%$ of the known risk to human health and the environment have been completed or placed in the remediation phase. 


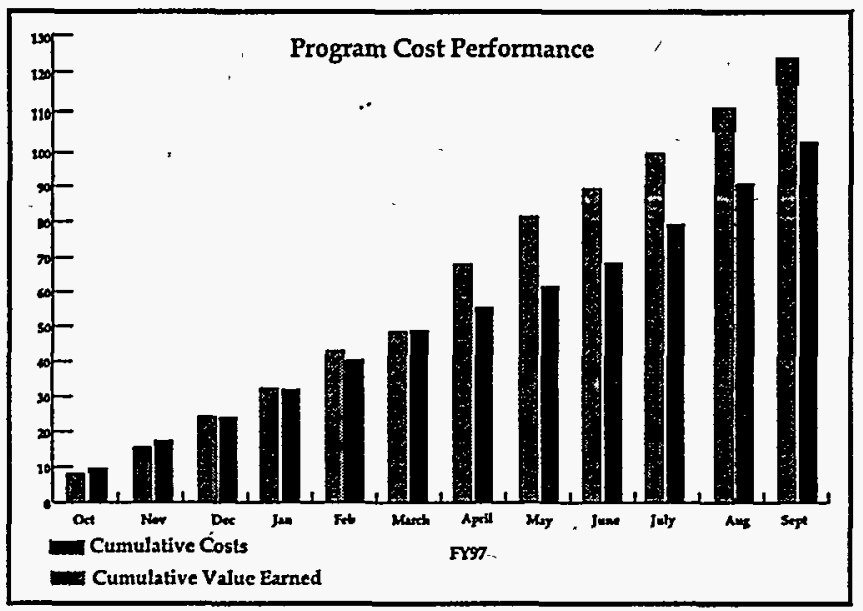

Effective planning and

execution throughout the year kept projects on schedule. Total available funds of $\$ 102 \mathrm{M}$ were utilized to accomplish over \$123M worth of approved scope.

All 85 Enforceable Agreement Milestones were met on time. $80 \%$ were accomplished ahead of schedule and average completion was 8 days early.
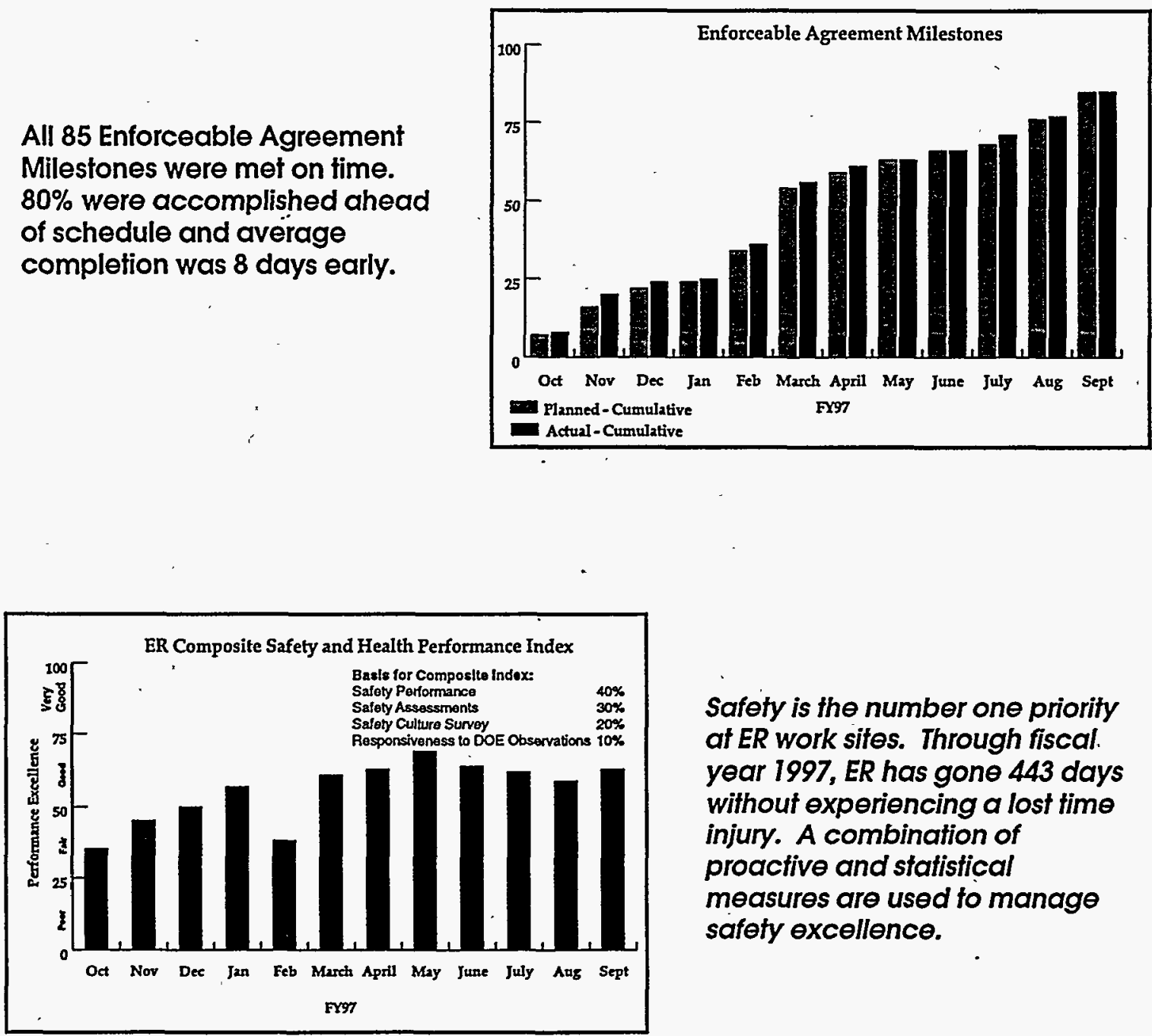

Safety is the number one priority at $E R$ work sites. Through fiscal. year 1997, ER has gone 443 days without experiencing a lost time injury. A combination of proactive and statistical measures are used to manage safety excellence. 
DOE has established the challenge to complete as much remediation work as possible by the year 2006. The SRS ER Strategic Plan includes five target goals that respond to the Cleanup 2006 challenge:

Focus on Remediation so that by the year 2006: 1) All high-risk waste sites will be remediated, 2) characterization and remedy selection for all currently identified waste sites and release areas will be complete, and 3) all groundwater remediation actions will be implemented.

Demonstrate Safety Excellence to perform ER work with no lost time accidents and achieve the best documented safety record in the DOE Complex.

Meet or Expedite Regulatory Requirements in a manner that builds regulator and public trust and confidence.

Maximize Deployment of Innovative Technologies for 1) improved construction/operations techniques, 2) in situ remediation alternatives, 3) non-invasive real-time characterization methods, and 4) waste minimization solutions

Demonstrate Cost-Effectiveness by accomplishing additional prioritized regulatory scope within annual operating budgets.

Although we are proud of the work accomplished in 1997, there is still a lot of work to do to complete cleanup of the Savannah River Site.

\section{Key accomplishments planned for 1998 include:}

- Achieve the Three-Billion Gallon mark for groundwater remediated and SixHundred Thousand Pounds of $\cdot V O C s$ removed in the A/M Areas.

- Complete dynamic compaction preparations and construction of a GeoSynthetic Cap to close the remaining 19 acres of the Low Level Radioactive Waste Disposal Facility.

- Complete startup testing and establish routine operations at the two new groundwater treatment systems in the $\mathrm{F} / \mathrm{H}$ Areas.

- Begin remedial action at the Old F-Area Seepage Basin and advance the L-Area Oil and Chemical Basin remedial action start to FY 98.

- Install two horizontal wells for in situ bioremediation at the Nonradioactive Disposal Facility.

- Certify the first mobile laboratories in the State of South Carolina for carrying out hazardous waste site contaminant analysis.

- Deploy In Situ Remediation Technology for Dense Non-aqueous Phase Liquids (DNAPLs).

- Complete all milestones supporting FFA Agreements including eight Records of Decision covering 16 units and 7 field starts for waste site characterization covering 13 units.

- Utilize new technology to-produce $\$ 5$ million in scope enhancements. 